Maurer School of Law: Indiana University

Digital Repository @ Maurer Law

2005

\title{
The Meaning of Moscow: "Non-Lethal" Weapons and International Law in the Early 21st Century
}

David P. Fidler

Indiana University Maurer School of Law, dfidler@indiana.edu

Follow this and additional works at: https://www.repository.law.indiana.edu/facpub

Part of the International Humanitarian Law Commons, and the International Law Commons

\section{Recommended Citation}

Fidler, David P., "The Meaning of Moscow: "Non-Lethal" Weapons and International Law in the Early 21st Century" (2005). Articles by Maurer Faculty. 2848.

https://www.repository.law.indiana.edu/facpub/2848

This Article is brought to you for free and open access by the Faculty Scholarship at Digital Repository @ Maurer Law. It has been accepted for inclusion in Articles by Maurer Faculty by an authorized administrator of Digital Repository @ Maurer Law. For more information, please contact rvaughan@indiana.edu. 


\section{The meaning of Moscow:} "Non-lethal" weapons and international law in the early 21 st century

\section{David P. Fidler}

David P. Fidler is Professor of Law and HarryT. Ke Faculty Fellow, Indiana University School of Law, Bloomington, USA.

\section{Abstract}

At the intersection of new weapon technologies and international humanitarian law, so-called "non-lethal" weapons have become an area of particular interest. This article analyses the relationship between "non-lethal" weapons and international law in the early 21st century by focusing on the most seminal incident to date in the short history of the "non-lethal" weapons debate, the use of an incapacitating chemical to end a terrorist attack on a Moscow theatre in October 2002. This tragic incident has shown that rapid technological change will continue to stress international law on the development and use of weaponry but in ways more politically charged, legally complicated and ethically challenging than the application of international humanitarian law in the past.

\section{Deciphering Moscow}

In the past decade, one of the most interesting areas produced by the intersection of new weapon technologies and international humanitarian law (IHL) involves so-called "non-lethal" weapons (NLWs). The technological, military, political, legal and ethical aspects of "non-lethal" weapons have generated significant attention and controversy. ${ }^{1}$ The growth in the size, complexity and intensity of the debate shows that this development is more than a post-Cold War fad. In reflecting on how the law has handled the emergence of technologies that proponents claim are different from "lethal" weapons, it is therefore 
appropriate to take stock of "non-lethal" weapons in relation to international humanitarian law specifically and international law in general. This article analyses the relationship between "non-lethal" weapons and international law in the early twenty-first century by focusing on the most seminal incident to date in the short history of the "non-lethal" weapon debate - the use of an incapacitating chemical to end a terrorist attack on a Moscow theatre in October 2002.

The emergence of weapon technologies is often defined by historical moments when their use tangibly reveals policy, legal and ethical issues that previously were abstract. The deployment of chemical weapons on World War I battlefields still contributes to how people think about such weapons. Perceptions of biological weapons are likewise darkened by the horrors of Japanese experimentation with them in China before and during World War II. The atomic explosions that devastated Hiroshima and Nagasaki in August 1945 continue to cast a pall over nuclear weapons. At the time of writing this article, the most significant real-world event to affect the NLW debate has been the use of an incapacitating chemical in Moscow in 2002. Although most relevant to the controversies surrounding "non-lethal" chemical weapons, the Moscow incident has broader implications for the relationship between NLW developments and the rules of international law examined below.

The article begins by reviewing how the debate on NLWs and international law unfolded prior to the Moscow incident. That period found many people, including myself, ${ }^{2,3}$ analysing the development and use of various NLWs in terms of existing international law, especially international law on arms control and IHL. These efforts revealed disagreements between proponents and sceptics as to international law's role in NLW development and use. In the absence of concrete events, evidence or data, the dialogue between proponents and sceptics retained an abstract quality that featured more conceptual speculation than empirical analysis. ${ }^{4}$

The article then describes the Moscow theatre incident and how this crisis transformed abstract features of the NLW debate into an actual life-anddeath event of far-reaching importance. One of the most important effects of

1 The literature on NLWs is now voluminous. For one bibliography on NLWs compiled by the Air University Library at Maxwell Air Force Base, see Non-Lethal Weapons, August 2004, at <http://www.au.af.mil/au/aul/ bibs/soft/nonlethal.htm >. Bibliography updates on NLWs are provided in the periodic Bradford Non-Lethal Weapons Research Project Reports, at <http://www.brad.ac.uk/acad/nlw/research_reports/> (last visited 22 June 2005).

2 David P. Fidler, "The international legal implications of 'non-lethal' weapons", Michigan Journal of International Law, Vol. 21, 1999, pp. 51-100.

3 David P. Fidler, "Non-lethal' weapons and international law: Three perspectives on the future", Medicine, Conflict and Survival, Vol. 17, 2001, pp. 194-206.

4 In 1999, I argued, for example, that "[g]iven the embryonic nature of 'non-lethal' weapons development and integration into military forces and strategies, much of the international legal analysis unfolds in a vacuum of precedent, which gives the analysis an abstract and, at times, speculative quality." Fidler, op. cit. (note 2), p. 55. 
the Moscow incident was to focus attention on how the Chemical Weapons Convention (CWC) $)^{5}$ regulated the use of incapacitating chemicals for law enforcement purposes, and the article interprets this aspect of the CWC in light of what happened in Moscow. Finally, the present and future relationship between NLWs and international law is examined in light of the aftermath of Moscow.

\section{Before Moscow: The debate on NLWs and international law}

The debate about the international legal implications of NLWs only developed in the latter half of the 1990s in response to increased interest in such weapons among military forces around the world, and particularly in the United States. Before then, international law had addressed weapons designed, or claimed, to be less lethal than conventional weapons. Treaties on biological, chemical, and conventional weapons regulated "non-lethal" capabilities. The Biological and Toxin Weapons Convention (BWC) prohibited the development of "non-lethal" biological weapons, whether for anti-personnel or antimatériel purposes. ${ }^{6}$ The CWC banned the development and use of chemical weapons, defined to include toxic chemicals that cause temporary incapacitation. $^{7}$ In addition, the CWC prohibited the use of riot control agents (RCAs) as a method of warfare. ${ }^{8}$ States added a protocol to the UN Conventional Weapons Convention in 1995 outlawing the use of laser weapons designed to cause permanent blindness. ${ }^{9}$

Although these examples are of international law regulating "non-lethal" weapons capabilities, no discourse centred on such weapons existed in international law before the mid-1990s. Growth in military and, to a lesser extent, law enforcement $^{10}$ interest in the latter half of the 1990s stimulated international legal analysis specifically of NLWs as a new category of weapons. (See Table 1 for descriptions of technologies.) Experts responded to claims that this weaponry was different not only technologically but also ethically from weapons that international law had long been trying to regulate through arms control treaties and IHL.

5 Convention on the Prohibition of the Development, Production, Stockpiling and Use of Chemical Weapons and on their Destruction, 13 January 1993, UNTS, Vol. 1974, p. 317 (hereinafter CWC).

6 Convention on the Prohibition of the Development, Production and Stockpiling of Bacteriological (Biological) and Toxin Weapons and on their Destruction, 10 April 1972, International Legal Materials, Vol. 11, 1972, p. 309 (hereinafter BWC).

7 Arts. I.1 and II.2, CWC.

8 Art. I.5, CWC.

9 Protocol on Blinding Laser Weapons (Additional Protocol IV to the UN Convention on Prohibitions or Restrictions on the Use of Certain Conventional Weapons Which May be Deemed to be Excessively Injurious or to Have Indiscriminate Effects of 1980), 13 October 1995, UN Doc. CCW/CONF.I/7, 12 October 1995.

10 NLWs were, of course, familiar to law enforcement agencies by the latter half of the 1990s because police and internal security forces had long used such weapons as plastic bullets, bean-bag rounds, riot control agents, water cannons, and batons. Law enforcement involvement and interest in NLWs seemed, however, to pick up at the same time military forces began to look more seriously at deploying these weapon technologies. 
Table 1. Leading NLW Technology Areas ${ }^{11}$

\begin{tabular}{|c|c|}
\hline NLW Technology & Examples \\
\hline Kinetic energy & $\begin{array}{l}\text { Impact munitions (foam rubber projectiles, wooden } \\
\text { dowels, bean bags, plastic bullets, water cannons, ring } \\
\text { airfoil projectile) }\end{array}$ \\
\hline $\begin{array}{l}\text { Barriers and } \\
\text { entanglements }\end{array}$ & $\begin{array}{l}\text { Devices to slow the progress of and stop vehicles or } \\
\text { boats (e.g. nets, chains, spikes, rigid foams) }\end{array}$ \\
\hline Electrical & $\begin{array}{l}\text { Electro-muscular disruption technology (e.g. Taser } \\
\text { stun guns, retractable "stun sword," exoskeleton } \\
\text { stun weapon, wireless electrical weapon (e.g. Close } \\
\text { Quarters Shock Rifle), laser-induced plasma weapon }\end{array}$ \\
\hline Acoustic & $\begin{array}{l}\text { Acoustic generators, acoustic cannon, long-range } \\
\text { acoustic devices }\end{array}$ \\
\hline Directed energy & $\begin{array}{l}\text { High power microwave, millimeter wave, lasers, } \\
\text { pulsed energy projectile weapon }\end{array}$ \\
\hline Chemical & $\begin{array}{l}\text { RCAs, malodorants, anti-traction materials, obscur- } \\
\text { ants, sticky foam, anti-matériel chemicals, defoliants/ } \\
\text { herbicides }\end{array}$ \\
\hline Chemical/biochemical & Calmatives, convulsants, incapacitants \\
\hline Biological & Anti-matériel microorganisms, anti-crop agents \\
\hline Combined technologies & $\begin{array}{l}\text { Flash-bang grenades, kinetic + chemical dispersal } \\
\text { devices, optical + chemical dispersal devices }\end{array}$ \\
\hline Delivery systems & $\begin{array}{l}\text { "Non-lethal" munitions (e.g. mortar shells), land } \\
\text { mines, unmanned vehicles and vessels, encapsulation/ } \\
\text { microencapsulation }\end{array}$ \\
\hline
\end{tabular}

The debate about the implications of NLWs for international law unfolded in a manner that heightened the debate's controversy. Generally speaking, the main thrust of international law with respect to weapon technologies in the late nineteenth century and most of the twentieth century was to craft and apply rules governing increasingly destructive and deadly weapons. ${ }^{12}$

"Non-lethal" weapons did not, however, fit into this pattern. As defined by the US Department of Defense, NLWs are weapons "that are explicitly

11 Nicholas Lewer and Neil Davison, "Non-lethal technologies: An overview," Disarmament Forum, 2005, pp. 37-51; Neil Davison and Nicholas Lewer, Bradford Non-Lethal Weapons Research Project Research Report No. 7, May 2005; and Neil Davison and Nicholas Lewer, Bradford Non-Lethal Weapons Research Project Research Report No. 6, October 2004.

12 This is best exemplified by the problem nuclear weapons presented for IHL - a topic addressed in 1996 in an advisory opinion by the International Court of Justice. See Legality of the Threat or Use of Nuclear Weapons, Advisory Opinion, 8 July 1996, ICJ Reports, 1996, p. 226. 
designed and primarily employed so as to incapacitate personnel or material, while minimizing fatalities, permanent injury to personnel, and undesired damage to property and the environment." 13 Defined in this way, "non-lethal" weapons echoed IHL's objective of making armed conflict more humane. ${ }^{14}$ In addition, exploration of NLWs was driven to some degree by the constraints IHL imposed on military forces engaging in non-traditional operations, such as peacekeeping. This seeming convergence of interests created a context in which military forces and international humanitarian lawyers and experts could perhaps embrace these new weapon technologies together.

That embrace did not occur. "Non-lethal" weapon advocacy met with scepticism from policy analysts, international lawyers, and those involved in international humanitarian work. ${ }^{15}$ Many people wondered why such experts were challenging more humane ways of warfare and peacekeeping. Although simplistic, the question threatened to wrong-foot those not enthusiastic about NLWs. Sceptics responded by pointing to the many unanswered questions for which international law required answers before weapons could legitimately be deployed. ${ }^{16}$ Nothing epitomized the distance separating advocates and sceptics better than disagreements about the moniker "non-lethal weapons."17 For proponents, this description encapsulated the technological and ethical distinctiveness of these weapons. For sceptics, the moniker was misleading because it gave moral status to weapons simply by virtue of their technology and not on the basis of legal and ethical analysis of why, how and where they are used.

This disagreement affected the international legal debate. Convinced that NLWs were ethically distinct weapons, proponents questioned international legal rules that might restrict development and use of NLWs and broached the need to consider changing such rules. A number of NLW advocates argued

13 Policy for Non-Lethal Weapons, US Department of Defense Directive No. 3000.3, para. C (9 July 1996). See also NATO Policy on Non-Lethal Weapons, NATO, 13 October 1999, at <http://www.nato.int/docu/ $\mathrm{pr} / 1999 / \mathrm{p} 991013 \mathrm{e} . \mathrm{htm}>$ (last visited 22 June 2005)("Non-Lethal Weapons are weapons which are explicitly designed and developed to incapacitate or repel personnel, with a low probability of fatality or permanent injury, or to disable equipment, with minimal undesired damage or impact on the environment.").

14 Jonathan D. Moreno, "Medical ethics and non-lethal weapons," American Journal of Bioethics, Vol. 4, 2004, p. W1 (noting that "NLWs seem to advance one of Augustine's requirements for just war: that only as much force be used as necessary for the task.").

15 Well-known early critiques of NLWs include Malcolm Dando, A New Form of Warfare: The Rise of NonLethal Weapons, Brassey's, London, 1996; Nicholas Lewer and Steven Schofield, Non-Lethal Weapons: A Fatal Attraction?, Zed Books, London, 1997; and Robin Coupland, "'Non-lethal' weapons: Precipitating a new arms race," British Medical Journal, Vol. 315, 1997, p. 72.

16 For example, 1977 Additional Protocol I requires States Parties to assess the legality of any new weapons, means or methods of warfare. Additional Protocol (I) to the Geneva Conventions of 12 August 1949, and Relating to the Protection of Victims of International Armed Conflicts, 8 June 1977, UNTS, Vol. 1125 , p. 3, Art. 36. On this obligation, see Isabelle Daoust, Robin Coupland, and Rikke Ishoey, "New wars, new weapons? The obligation of States to assess the legality of means and methods of warfare," International Review of the Red Cross, Vol. 84, No. 846, June 2002, pp. 345-363; Justin McClelland, "The review of weapons in accordance with Article 36 of Additional Protocol I," International Review of the Red Crass, Vol. 85, No. 850, June 2003, pp. 397-415.

17 For discussion of the term "non-lethal weapons," see Brian Rappert, Non-Lethal Weapons as Legitimating Forces? Technology, Politics and the Management of Conflict, Frank Cass, London, 2003, pp. 17-34. 
that treaties restricting their development should be amended. ${ }^{18}$ This position highlighted the restrictions of the BWC and the CWC on development of "nonlethal" biological and chemical weapons.

But sometimes the proponents' views hinted at more radical ideas, such as rethinking the moral framework that had historically guided international law on armed conflict and replacing it with one that recognized new military and ethical contexts made possible by NLW technologies. ${ }^{19}$ This radical perspective can be sensed in the potential impact of "non-lethal" weapons on the traditional international humanitarian law rule prohibiting the use of weapons intentionally against civilian populations. ${ }^{20}$ Advocacy for NLWs raised the question whether this prohibition was ethically sustainable, given the increasing likelihood of armed conflict in urban areas. Would not the intentional use of an NLW against mixed combatant and non-combatant populations create the possibility of causing fewer civilian deaths and casualties than would result from limiting military forces to "lethal" weapons in an environment where making distinctions between combatants and non-combatants proves next to impossible and militarily disadvantageous? ${ }^{21}$

Convinced that "non-lethal" weapons were simply weapons without any special ethical status, sceptics applied existing international law on arms control, use of force, armed conflict, and human rights to argue that these weapons generated many serious legal and ethical questions that should not be obscured by "non-lethal" rhetoric. Moreover, sceptics insisted that development and use of NLWs must comply with existing, and future, international law. ${ }^{22}$ Opposition was strongest when proponents argued that important international legal rules should be changed or rejected to make way for NLWs. Alarm bells rang loudest with respect to "non-lethal" weapons that potentially could undermine the $\mathrm{BWC}$ and CWC. ${ }^{23}$

Proponents and sceptics agreed, however, on one thing: the debate on "non-lethal" weapons and international law was mainly about future technologies, not NLWs deployable in the latter half of the 1990s and early 2000 s. Although this debate covered plastic bullets, bean-bag rounds, entangling nets, caltrops, sticky foam, riot control agents, flash-bang grenades, and simi-

18 In earlier writing, I referred to these arguments as the "selective change perspective". Fidler, op. cit. (note 3), pp. 199-201.

19 In earlier writing, I called this position the "radical change perspective." Ibid., pp. 201-204.

20 Robin Coupland, "Calmatives' and 'incapacitants': Questions for international humanitarian law brought by new means and methods of warfare with new effects?", in Davison and Lewer 2004, op. cit. (note 11), p. 35, p. 38 ("Another major concern in relation to 'non-lethal' weapons is that their proponents propose they be used by soldiers against civilians when necessary.").

21 Jefferson D. Reynolds, "Collateral damage on the 21 st century battlefield: Enemy exploitation of the law of armed conflict, and the struggle for a moral high ground," Air Force Law Review, Vol. 56, 2005, p. 1, pp. 99-100 ("Perhaps most promising of all are non-lethal weapons that can be applied against enemy combatants commingled with civilians.").

22 In earlier writing, I called this the "compliance perspective". Fidler, op. cit. (note 3), pp. 198-199.

23 "Non-lethal' weapons, the CWC and the BWC," CBW Conventions Bulletin, No. 61, September 2003, p. 1 (arguing that "as investment mounts in emergent 'non lethal weapons' (NLW) technologies, it becomes increasingly urgent that the threat they pose to the CWC and BWC regime be recognised."). 
lar technologies, such low-tech NLWs were not the most important issue for their proponents and sceptics. The existing generation had limited capabilities because they utilized mainly short-range mechanical, chemical or kinetic technologies. The debate was really about what people called the "Buck Rogers stuff," the next generation of NLWs that would harness higher-tech kinetic, acoustical, electrical, electromagnetic, biological, chemical and other potential futuristic capabilities, such as nanotechnology. ${ }^{24}$

For this reason, advocates and sceptics were largely engaging in "crystal ball" speculation in analysing how "non-lethal" weapons might affect armed conflict. Advocates believed NLWs could make battlefields less lethal; sceptics cautioned that these weapons could act as force multipliers for "lethal" weapons, making battlefields more, not less, deadly. From an international legal perspective, such speculation differed depending on the "density" of the international legal regime relevant to a given NLW technology. The most concentrated regimes banned both the development and use of certain technologies, such as the general prohibitions on biological and chemical weapons.

The less concentrated regimes did not specifically ban certain technologies but applied general rules to the development and use of weapons. For example, no treaty directly regulates the development or use of a microwave weapon. However, IHL applies general disciplines to any use of a microwave weapon, including requirements that such use must distinguish between combatants and non-combatants ${ }^{25}$ and must not cause superfluous injury or unnecessary suffering to combatants. ${ }^{26}$ For want of either the new technologies or empirical data on their use, discourse about NLWs in the areas where international legal regulation was less concentrated was the most speculative, often because the outcome of analysis depended on the actual intent and behaviour of soldiers.

The "crystal ball" context had, however, two effects that put the proponents on the defensive. First, the case for developing the next generation of technologies largely hinged on their "non-lethality." Without being able to establish that a new technology was empirically "non-lethal," the ethical force for developing such a technology was weaker. Data on the human effects of most current or proposed NLWs were non-existent, scant or not supportive of a claim for "non-lethality." ${ }^{27}$ Proponents had thus taken the debate down a

24 Center for Responsible Nanotechnology, Dangers of Molecular Manufacturing, at <http://www.crnano.org/ dangers.htm\#arms> (last visited 22 June 2005), describing possible implications of nanotech weapons.

25 Jean-Marie Henckaerts, "Study on customary international humanitarian law: A contribution to the understanding and respect for the rule of law in armed conflict," International Review of the Red Cross, Vol. 87 , No. 857 , March 2005 , p. 175 , p. 198 (stating that, under customary IHL, "[t]he parties to the conflict must at all times distinguish between civilians and combatants. Attacks may only be directed against combatants. Attacks must not be directed against civilians.").

26 Ibid., p. 204 (stating that, under customary IHL, "[t] he use of means and methods of warfare which are of a nature to cause superfluous injury or unnecessary suffering is prohibited.").

27 Fidler, op. cit. (note 2), p. 62 (describing studies at the end of the 1990s which concluded that no existing NLWs met criteria for qualifying as "non-lethal"). For more recent descriptions of health impact issues, see Lewer and Davison, op. cit. (note 11), p. 48-49; Davison and Lewer 2005, op. cit. (note 11), p. 28. 
path that required them to establish the human effects of NLW technologies. The ethical threshold they set imposed an empirical price on research and development $(R \& D)$ that had yet to be paid. ${ }^{28}$

The second effect also resulted from ethical claims advocates made. If non-lethal weapons were ethically superior, some experts asked, then, ethically, do governments have an obligation to use these weapons first before resorting to "lethal" force? Proponents countered this ethical argument with a legal one: international law does not require the use of "non-lethal" force before the use of "lethal" force in armed conflict. ${ }^{29}$ Although correct in terms of international law, the legal response did not answer the ethical question. How could one advocate the development of ethically superior weapons and not have an ethical obligation to use such weapons before "lethal" ones? To be sure, this question leaves out much that would be ethically relevant to the choice of weapons in armed conflict, but it brought potential ethical inconsistencies in NLW advocacy to light. Such ethical questions combined with empirical uncertainty about the human effects of NLW technologies, created difficulties for their proponents in the international legal debate.

The emergence of sustained debate about "non-lethal" weapons and international law in the latter half of the 1990s revealed that neither side had bested the other in the initial test of strength and that both were gearing up for issues that would be raised by pursuit of more high-tech NLWs. Despite increasing numbers of conferences, articles, books and reports, missing from the debate was an event that would sharpen issues and expand political and policy interest in the questions being examined by NLW proponents and sceptics.

And then, in October 2002, Chechen terrorists took over a theatre in Moscow.

\section{During Moscow: The fog of fentanyl}

The Chechen assault on the Nord-Ost Theatre in Moscow, and the crisis involving approximately 830 hostages, ended when Russian security forces pumped an incapacitating chemical, believed to be a derivative of the opiate fentanyl, into the theatre as a prelude to storming the building. Russian forces killed all the terrorists and rescued hundreds of hostages. The fentanyl, however, killed approximately 130 hostages - a fatality rate of $16 \%$, more than twice the fatal-

28 Some NLW advocates have expressed frustration at the attention paid to the lack of empirical data on the human effects of NLWs. See Davison and Lewer 2005, op. cit. (note 11), p. 21 (reporting on NLW advocate John Alexander's dismissal of "concerns over insufficient data about the human effects of NLWs." ).

29 NATO, op. cit. (note 13): "Neither the existence, the presence nor the potential effect of Non-Lethal Weapons shall constitute an obligation to use Non-Lethal Weapons, or impose a higher standard for, or additional restrictions on, the use of lethal force." But see Davison and Lewer 2005, op. cit. (note 11), p. 27 (describing NLW legal expert David Koplow arguing that the current state of international law on this issue "was unlikely to "hold" " and predicting "that in the future NLWs would indeed raise the threshold for use of lethal force."). 
ity rate of "lethal" chemical weapons used on World War I battlefields. ${ }^{30}$ The use of an incapacitating chemical to end the Moscow hostage crisis hit the debate about NLWs and international law like a thunderbolt.

Russia's use of fentanyl had two immediate effects on that debate. The first effect was to raise the profile of the controversy surrounding incapacitating chemicals as potential NLWs. As explored below, what happened in Moscow drew new attention to the way in which the CWC addressed the use of such chemicals. Moscow made the CWC's relationship to incapacitating chemicals more important both politically and legally, raising the stakes of this aspect of the debate on NLWs and international law.

Second, the Moscow crisis produced what I call the "fog of fentanyl" because the use of the incapacitating chemical gave both sides of the debate material they could use, clouding rather than clarifying issues in the controversy. For advocates, Moscow represented the kind of scenario that required thinking more seriously about NLWs. The combination of incapacitating fentanyl and conventional force saved most of the hostages, a result the use of conventional force alone would not have produced. The ability to bring "non-lethal" and "lethal" capabilities to bear appeared to save lives. Given the predictions about the threat terrorism poses after 11 September 2001, what happened in Moscow suggested to advocates that more vigorous pursuit of NLWs was needed with respect to non-traditional law enforcement, security, and military threats.

But Moscow also provided sceptics with evidence to support their views. The death toll from the fentanyl demonstrated that incapacitating chemicals are not "non-lethal." Use of fentanyl in a context in which neither dosage nor exposure environment could be controlled resulted in a significant fatality rate among those exposed. These fatalities supported the sceptics' claims that NLWs should be considered simply as weapons, the dangers of which depend on many factors that must be evaluated on a case-by-case basis and not obscured by a misleading, politically correct moniker.

Moscow intensified the sceptics' fears that interest in incapacitating chemicals would increase, threatening the CWC. The manner in which Russian security forces killed all the incapacitated terrorists reinforced international humanitarian concerns about how NLWs might encourage military forces to violate the IHL principle of 'hors de combat." ${ }^{31}$ The fentanyl-related fatalities among the hostages raised human rights questions about the Russian government's behaviour, particularly its lack of preparedness to deal with fentanylaffected persons in the aftermath of the theatre's storming. ${ }^{32}$

30 Alexander Kelle, "Science, technology and the CBW control regimes," Disarmament Forum, 2005, p. 8, p. 10. For a report on health problems suffered by the hostage survivors two years later, see Anna Rudnitskaya, "Nord-Ost tragedy goes on," The Moscow News, Issue No. 41, 2004, at <http://english.mn.ru/ english/issue.php?2004-41-2> (last visited 22 June 2005).

31 Henckaerts, op. cit. (note 25), p. 203 (stating that, under customary IHL, "[a]ttacking persons who are recognized as hors de combat is prohibited.").

32 Independent Commission of Inquiry Must Investigate Raid on Moscow Theater: Inadequate Protection for Consequences of Gas Violates Obligation to Protect Life, Human Rights Watch, 30 October 2002, at <http://www.hrw.org/press/2002/10/russia1030.htm> (last visited 20 June 2005). 
The "fog of fentanyl" meant that, dramatic as the Moscow incident was, the use of the incapacitating chemical did not resolve the debate about NLWs and international law. As the most significant real-world event involving an NLW beyond traditional kinetic and mechanical devices and riot control agents, the Moscow crisis heightened the debate's importance, especially with regard to "non-lethal" chemical weapons. The next two sections look more closely at the impact of the Moscow incident on the NLW-international law debate, starting with the issue of the CWC's regulation of incapacitating chemicals and then exploring the broader consequences of Moscow for the future relationship between these weapons and international law.

\section{After Moscow: Incapacitating chemicals and the CWC}

\section{The impact of Moscow on the CWC}

The aspect of the debate about "non-lethal" weapons and international law that has the longest history relates to "non-lethal" chemical weapons. The CWC negotiations dealt with the controversy as to whether riot control agents could be used as a method of warfare. ${ }^{33}$ In addition, CWC negotiators addressed the use of toxic chemicals for purposes related to law enforcement. ${ }^{34}$ The emergence of interest in NLWs in the latter half of the 1990s led their advocates to argue that CWC strictures on the military use of RCAs and incapacitating chemicals ought to be revisited and perhaps changed, ${ }^{35}$ an argument colourfully captured by one expert who asserted that "chemicals can be our friends." 36

The use of fentanyl during the Moscow crisis focused renewed attention on the CWC's handling of incapacitating chemicals, especially Article II.9(d), which allows the use of toxic chemicals for law enforcement purposes. ${ }^{37}$ This law enforcement provision had caused concern during and after the CWC's negotiation, ${ }^{38}$ but questions about its scope and potential impact on the CWC lingered until the Moscow crisis, ${ }^{39}$ which made such questions unavoidable and significant in terms of the CWC and the broader debate concerning NLWs

33 Art. I.5, CWC.

34 Ibid., Art. II.9(d).

35 See, e.g. Nonlethal Technologies: Progress and Prospects, Independent Task Force, Council on Foreign Relations, New York, 1999, at <http://www.cfr.org/pub3326/richard_l_garwin_w_winfield/nonlethal_ technologies_progress_and_prospects.php\#Report> (last visited 22 June 2005), arguing, in connection with chemical and biological weapons, that US security might be enhanced by modifying treaties.

36 Russell Glenn, "Separating the wheat from the chaff: Non-lethal capabilities in future urban operations", paper presented at Jane's 4th Annual Non-Lethal Weapons 2000 Conference, 5 December 2000.

37 Art. II.9(d), CWC, which stipulates that "'Purposes Not Prohibited Under this Convention' means: (...) (d) Law enforcement including domestic riot control purposes.").

38 For example, an editorial in the Chemical Weapons Convention Bulletin focused on the law enforcement provision in Article II.9(d) and asked "what is "law enforcement"? ... Whose law? What law? Enforced where? By whom?". "New weapon technologies and the loophole in the Convention," Chemical Weapons Convention Bulletin, No. 23, March 1994, p. 1.

39 An editorial in the $C B W$ Conventions Bulletin returned to the issue after the Moscow incident and asked "what in the context of the Convention is 'law enforcement'?" "Law enforcement' and the CWC" CBW Conventions Bulletin, No. 58, December 2002, p. 1. 
and international law. Most experts agreed that what happened in Moscow fell within the CWC's law enforcement provision, and this consensus added more anxiety to controversies about how the provision should be interpreted..$^{40}$

The stakes with regard to the interpretation of the law enforcement provision were high for proponents and sceptics. For sceptics, the provision represented a potential loophole that proponents of incapacitating chemical weapons could exploit to undermine the CWC's prohibition on the military anti-personnel use of incapacitating chemicals. ${ }^{41}$ For advocates, the law enforcement provision offered room to develop the potential of incapacitating chemicals and demonstrate their utility for both law enforcement purposes and missions the military would face in twenty-first-century armed conflict. The provision was thus a platform from which an argument could be built that the CWC's prohibition on the military use of RCAs and incapacitating chemicals should be revised to reflect new "non-lethal" capabilities in the chemical field. In this sense, the law enforcement provision was a potential gateway to more robust "non-lethal" chemical capabilities for law enforcement personnel and military forces.

How the law enforcement provision would be interpreted after Moscow consequently became a policy and legal question of the highest order for the debate on NLWs and international law, and this article now turns to the interpretation of that provision and the implications of that interpretation for the future of this debate. ${ }^{42}$

\section{What toxic chemicals can be used for law enforcement purposes?}

The initial interpretative question concerned the permissible range of toxic chemicals that can be used for law enforcement. Article II.9(d) clearly brings riot control agents within the range of permissible chemicals. ${ }^{43}$ Some experts have claimed that any toxic chemical used for law enforcement purposes has to have the same properties as an RCA. ${ }^{44}$ This interpretation is wrong for four reasons.

40 Another factor enhancing the importance of the meaning of the CWC's law enforcement provision was the convening in the spring of 2003, approximately six months after the Moscow incident, of the First Review Conference of the CWC. When CWC States Parties failed at that Conference to address the issues raised by the Moscow crisis, the controversy deepened.

41 The CWC does not prohibit the use of toxic chemicals for anti-matériel purposes in contexts in which the anti-matériel use of toxic chemicals does not adversely affect humans or animals. See Fidler, op. cit. (note 2), p. 72.

42 The interpretation of the CWC's law enforcement provision in this article is based on the author's previous analysis of this question, which was first presented to the open forum for non-governmental organizations at the CWC's First Review Conference in May 2003 and then in revised form as David P. Fidler, "Background paper on incapacitating chemical and biochemical weapons and law enforcement under the Chemical Weapons Convention", 25 May 2005, prepared for a symposium on incapacitating biochemical weapons in June 2005.

43 Art. II.7, CWC, (defining an RCA as "[a]ny chemical not listed in a Schedule, which can produce rapidly in humans sensory irritation or disabling physical effects which disappear within a short period of time following termination of exposure").

44 Abraham Chayes and Matthew Meselson, "Proposed guidelines on the status of riot control agents and other toxic chemicals under the Chemical Weapons Convention", Chemical Weapons Convention Bulletin, No. 35, March 1997, p. 13; Walter Krutzsch, "Non-lethal' chemicals for law enforcement?" Berlin Information and Center for Transatlantic Security Research Note 03.2, April 2003, p. 4. 
First, Article II.9(d) allows countries to use toxic chemicals for capital punishment, and the chemicals used for this purpose are not RCAs. ${ }^{45}$

Second, treaty interpretation rules do not support restricting Article II.9(d) to toxic chemicals that are RCAs. Under international law, a treaty must be interpreted "in good faith in accordance with the ordinary meaning to be given to the terms of the treaty in their context and in the light of its object and purpose." 46

Article II.1(a) of the CWC states: "Chemical Weapons' means the following, together or separately: (a) Toxic chemicals and their precursors, except where intended for purposes not prohibited under this Convention, as long as the types and quantities are consistent with such purposes." Thus, "toxic chemicals" are chemical weapons except where intended for purposes not prohibited by the CWC, such as law enforcement. The law enforcement provision applies, therefore, to "toxic chemicals" as defined in Article II.2 ${ }^{47}$ not just to riot control agents as defined in Article II.7. Article II.1(a) does not mention RCAs as a limitation on the "toxic chemicals" that can be used for purposes not prohibited under the CWC.

Third, riot control agents are defined as chemicals that are not listed on any Schedule to the CWC. ${ }^{48}$ Toxic chemicals that can be used for purposes which are not prohibited, including law enforcement, can be listed on Schedules 2 and 3 of the CWC. The CWC's Verification Annex makes this clear: a CWC State Party may not produce, acquire, retain, or use Schedule 1 chemicals unless, among other things, "[t]he chemicals are applied to research, medical, pharmaceutical or protective purposes." ${ }^{19}$ Law enforcement is not listed as a purpose for which Schedule 1 chemicals may be produced, acquired, retained, or used. As Krutzsch and Trapp observed, the Verification Annex relating to Schedule 1 chemicals is more restrictive than Article II.9, which means that "a Schedule 1 chemical cannot be used for any other purposes than those listed even if such a purpose were a peaceful one not related to the development, production or use of a chemical weapon." ${ }^{\text {. }}$

The Verification Annex on Schedule 1 chemicals thus means that CWC States Parties cannot produce, acquire, retain, or use Schedule 1 chemicals for law enforcement purposes. By contrast, the Verification Annex on Schedule 2 and 3 chemicals does not restrict in the same manner the purposes that are not

45 Some who have advocated restricting the range of toxic chemicals for law enforcement to those that meet the RCA definition admit that lethal doses of toxic chemicals can be used in capital punishment. Chayes and Meselson, op. cit. (note 44), p. 13 and Krutzsch, op. cit. (note 44).

46 Art. 31.1 of the Vienna Convention on the Law of Treaties, 23 May 1969, UNTS, Vol. 1155, p. 331 (hereinafter Vienna Convention).

47 Article II.2 of the CWC defines "toxic chemical" to mean: "Any chemical which through its chemical action on life processes can cause death, temporary incapacitation or permanent harm to humans or animals. This includes all such chemicals, regardless of their origin or of their method of production, and regardless of whether they are produced in facilities, in munitions or elsewhere. (For the purpose of implementing this Convention, toxic chemicals which have been identified for the application of verification measures are listed in Schedules contained in the Annex on Chemicals.)"

48 Art. II.7, CWC.

49 Ibid., Verification Annex, Part VI, A.2(a).

50 Walter Krutzsch and Ralf Trapp, A Commentary on the Chemical Weapons Convention, Martinus Nijhoff Publishers, The Hague, 1994, p. 418. 
prohibited, meaning that toxic chemicals listed on Schedules 2 or 3 , which cannot be RCAs, may be employed for law enforcement purposes.

Fourth, in the Moscow incident the use of a toxic chemical that is not an RCA for law enforcement purposes provides some evidence of State practice that the CWC does not limit the range of chemicals that can be used under Article II.9(d) to RCAs. Under international law, subsequent State practice under a treaty can be taken into account when interpreting a treaty. ${ }^{51}$ The State practice generated by the Moscow incident comprises not only Russia's use of the toxic chemical but also acquiescence of other CWC States Parties to such use. As Mark Wheelis noted, "most analysts consider the Russian use of a fentanyl derivative to have been legal" under Article II.9(d). ${ }^{52}$ Thus, international law on treaty interpretation indicates that the CWC does not limit the range of toxic chemicals that can be used for law enforcement purposes to riot control agents.

\section{CWC limitations on the development and use of toxic chemicals for law enforcement purposes}

Even though the CWC does not restrict law enforcement use of toxic chemicals to RCAs, such use is subject to the requirement that the types and quantities of chemicals developed, produced, acquired, stockpiled, retained, transferred, or used must be consistent with such permitted purposes. ${ }^{53}$ These limitations ensure that development, possession, and use of toxic chemicals for law enforcement do not undermine the CWC's prohibition on the development and use of toxic chemicals for military purposes. As with other provisions of this treaty, these disciplines must be interpreted in good faith to ascertain their ordinary meaning in light of their context and of the treaty's object and purpose.

The "types and quantities" rule requires scrutiny of the relationship between the chemical used and the law enforcement objective in question. The more difficult it is to control the effects of a chemical in a law enforcement operation, the more suspect such use is in terms of the agent being of a type or quantity consistent with a law enforcement purpose. This interpretation resonates with concerns about the deaths caused in Moscow by use of an incapacitating chemical. ${ }^{54}$

51 Art. 31.3(b), Vienna Convention.

52 Mark Wheelis, "Will the new biology lead to new weapons?" Arms Control Today, July/August 2004, p. 6, p. 8. This analysis does not suggest that State practice from one incident can settle interpretative questions raised by the CWC, but the State practice generated by the Moscow hostage situation is an important instance of State practice under Article II.9(d).

53 Art. II.1(a), CWC. Krutzsch and Trapp observed that "a State Party has not only to demonstrate that there was a legitimate intent for the production or stockpiling of a certain chemical, but also that the chemical is in fact of a type consistent with that purported intent, and that its quantity corresponds to the specified purpose." Krutzsch and Trapp, op. cit. (note 50), p. 27.

54 "As with any chemical incapacitants, the concentration of fentanyl in any particular part of the building will have been difficult to control, the effects of any given concentration of fentanyl on any particularly susceptible individual would not have been known, and achievement of a certain separation between the incapacitating and lethal effects of the drug in other words, discriminating between making people unconscious without stopping them breathing is very difficult." Malcolm Dando, "The danger to the Chemical Weapons Convention from incapacitating chemicals, First CWC Review Conference Paper No. 4, March 2003, p. 4. 


\section{Extreme law enforcement situations}

Use of incapacitating chemicals in contexts in which neither individual dosage nor the exposure conditions can be controlled is thus legitimate only in extreme situations. Extreme law enforcement situations are those in which governments confront the need to resort to potentially lethal force to resolve urgent, life-threatening situations because less violent and dangerous means of resolving the problems have failed. The Moscow crisis qualified as an extreme law enforcement situation. ${ }^{55}$ In the absence of such an extreme situation, a government is not using an incapacitating chemical agent of a type, or in a quantity, consistent with law enforcement purposes when it can control neither dosage nor exposure conditions.

International human rights law (IHRL), as a relevant body of international law under treaty interpretation rules, ${ }^{56}$ supports this conclusion. In extreme law enforcement situations, governments contemplating use of incapacitating chemicals confront the obligation to protect the right to life. ${ }^{57}$ This obligation prohibits governments from arbitrarily taking the lives of persons subject to their jurisdictions, ${ }^{58}$ and IHRL does not permit any derogation from this obligation, even in time of public emergency. ${ }^{59}$

Human rights organizations have accused Russia of violating the right to life by failing to provide adequate medical services to rescued hostages who succumbed to the fentanyl gas. ${ }^{60}$ The inability to control dosage or exposure environment if incapacitating chemicals are used in extreme law enforcement emergencies heightens a government's responsibility to ensure all precautions are taken to minimize harm to innocent people and to provide immediate medical attention to those exposed and perhaps adversely affected. ${ }^{61}$

\section{Law enforcement detention of individuals}

This interpretation means that the "types and quantities" restraint on use of incapacitating chemicals for non-extreme law enforcement situations requires CWC States Parties to maintain strict control over dosage and exposure envi-

55 As Human Rights Watch commented on the Moscow hostage incident, "International law does not prohibit the use of potentially lethal force in operations to liberate hostages, but it requires that such force be 'absolutely necessary' and that all precautions be taken in both the planning and execution of such operations to minimize the loss of civilian life." Human Rights Watch, op. cit. (note 32).

56 Art. 31.3(c), Vienna Convention, ("There shall be taken into account, together with the context: ... (c) any relevant rules of international law applicable in the relations between the parties.").

57 Art. 3, Universal Declaration of Human Rights, G.A. Res. 217A (III), UN Doc. A/810, 1948, p. 71 (hereinafter UDHR); Art. 6, International Covenant on Civil and Political Rights, 19 Dec. 1966, UNTS, Vol. 999, p. 171 (hereinafter ICCPR).

58 Human Rights Committee, "General Comment No. 6, Article 6", para. 3, in Compilation of General Comments and General Recommendations Adopted by Human Rights Treaty Bodies, UN Doc. HRI/ GEN/1/Rev/1, 1994, p. 6.

59 Art. 4, ICCPR.

60 Human Rights Watch, op. cit. (note 32).

61 Commenting on the possible use of incapacitating chemicals for law enforcement purposes, the British government argued: "The decision to use any drug whether intended to induce a state of calm or complete unconsciousness requires knowledge of a subject's medical history, particularly the use of any prescribed or nonprescribed medication and any relevant medical conditions. There would also be considerable responsibility in terms of immediate and post-incident aftercare." Quoted in Lewer and Davison, op. cit. (note 11), p. 47. 
ronment. ${ }^{62}$ Such control would mean that law enforcement authorities have to have physical custody of the individual in question. In keeping with rules on treaty interpretation, the "types and quantities" rule has to be interpreted in light of relevant international law applicable between States. ${ }^{63}$ Thus, a law enforcement situation involving physical custody of persons brings IHRL into the analysis. ${ }^{64}$ International law on civil and political rights directly addresses law enforcement activities. ${ }^{65} \mathrm{~A}$ reading of the "types and quantities" rule in light of human rights law considerably limits the contexts in which law enforcement authorities could use incapacitating chemicals against detained persons.

International human rights law prohibits torture or other cruel, inhuman, or degrading treatment or punishment and permits no derogations from this prohibition. ${ }^{6}$ Non-consensual, non-therapeutic use of an incapacitating chemical against detained individuals would constitute degrading treatment and could, depending on the severity of the chemical's physiological effects, constitute cruel or inhuman treatment and perhaps even torture. ${ }^{67}$ States, international organizations and non-governmental human rights organizations have long condemned the non-consensual, non-therapeutic use of psychotropic drugs and other types of chemicals against detained persons. The only contexts in which non-consensual, non-therapeutic use of an incapacitating chemical on a detained person might be compatible with IHRL are situations in which the detained person poses an immediate, violent threat to his or her own physical safety (e.g. attempting suicide) or to safety and order in the detention facility (e.g. attacking guards or participating in riots).

Thus, law enforcement purposes for which incapacitating chemicals may be legitimately used on physically detained persons are extremely limited under the CWC's "types and quantities" rule. Key to this interpretation is the relevance of IHRL in determining the types and quantities of incapacitating chemicals that can legitimately be used for law enforcement purposes connected to the detention of individuals.

Summary: CWC limitations on development and use of toxic chemicals for law enforcement

Overall, the "types and quantities" rule significantly restrains a CWC State Party's ability to develop and use incapacitating chemicals for law enforcement

62 "To elicit the desired level of mood alteration without causing a dangerous level of respiratory depression (i.e. calming while maintaining consciousness) requires a tight control on dose level." An Assessment of Non-Lethal Weapons Science and Technology, Committee for an Assessment of Non-Lethal Weapons Science and Technology, National Academies Press, Washington, D.C., 2003, p. 27.

63 Art. 31.3(c), Vienna Convention.

64 The CWC was negotiated well after the development of IHRL, which strengthens the legitimacy of making reference to IHRL in the interpretation of the CWC's law enforcement provision.

65 See, e.g. Arts. 6 ICCPR (no arbitrary deprivation of life and rules on imposition of the death penalty), 7 (prohibition of torture or cruel, inhuman or degrading treatment or punishment), 9-10 (rules relating to the deprivation of liberty), and 14-15 (rules on charging and prosecuting individuals for criminal offences).

66 Art. 5 UDHR; Arts. 4.2 and 7 ICCPR.

67 Detailed analysis of these IHRL issues can be found in Fidler, op. cit. (note 42), pp. 33-44. 
purposes, whether those purposes involve groups of people or detained individuals. The legal "loophole" in Article II.9(d) is not, in fact, as dangerous as some NLW sceptics feared. The CWC, informed by IHRL, sets serious limits to a State's development and use of incapacitating chemicals for law enforcement purposes. Bringing IHRL to bear on the interpretation of the "types and quantities" limitation conforms to the ethical objectives to which "non-lethal" weapons proponents attribute their interest in incapacitating chemicals. NLW proponents would be acting inconsistently from an ethical standpoint if they rejected the application of human rights norms to the law enforcement use of incapacitating chemicals. Thus, the positions of sceptics and proponents converge with respect to the interpretation of the "types and quantities" rule presented above.

\section{The meaning of "law enforcement"}

The second major question to arise in connection with the interpretation of Article II.9(d) in the aftermath of Moscow was the scope of the term "law enforcement." Agreement that Russia's use of fentanyl was for law enforcement purposes gave rise to concern and confusion about exactly how far "law enforcement" stretched with respect to the use of incapacitating chemicals. As Dando asked, "when (...) does law enforcement end and a method of warfare begin?"68 The CWC does not define "law enforcement", which requires again engaging in treaty interpretation. The basic question is whether "law enforcement" should be interpreted narrowly or broadly. ${ }^{69}$ As discussed below, the choice also involves deciding whether "law enforcement" includes activities relating to international law.

\section{Enforcement of domestic law}

What is meant by "law enforcement"? The ordinary meaning of "enforcement" is to compel observance or obedience. ${ }^{70}$ The ordinary meaning of "law" clearly has the connotation of domestic law, or the law that applies to activities within the territory, or subject to the jurisdiction, of a sovereign State. Article II.9(d) of the CWC is concerned, therefore, with the enforcement of domestic law. Article II.9(d) allows lethal doses of toxic chemicals to be used for capital punishment - a law enforcement function that takes place within a State's jurisdiction. In addition, Article II.9(d) allows toxic chemicals to be used for "[1]aw enforcement including domestic riot control purposes." The phrase "including domestic riot control" illustrates one kind of law enforcement activity permitted by Article II.9(d) and focuses attention on domestic law enforcement within a

68 Malcolm Dando, "Scientific and technological change and the future of the CWC: The problem of nonlethal weapons," Disarmament Forum, 2002, pp. 33-34.

69 Krutzsch and Trapp spelled out this choice: "The phrase "law enforcement including domestic riot control' can be interpreted as meaning that there is riot control other than domestic riot control. On the other hand, that 'non-domestic' riot control would have to be an internationally accepted means of 'law enforcement." Krutzsch and Trapp, op. cit. (note 50), p. 42 n. 45.

70 Shorter Oxford English Dictionary, Oxford University Press, Oxford, 1993, p. 820. 
State's borders or jurisdiction. ${ }^{71}$ Russia's use of fentanyl occurred within its territory in response to violent, criminal acts. Although Article II.9(d) covers the enforcement of domestic law within a State's sovereign territory, two questions linger: does Article II.9(d) support the use of toxic chemicals to enforce domestic law extrajurisdictionally, and to enforce international law?

\section{Use of toxic chemicals in extrajurisdictional enforcement of domestic law} To analyse whether Article II.9(d) allows the use of toxic chemicals in the extrajurisdictional enforcement of domestic law, the rules of international law on this issue must be taken into account. It is clear from these rules that the CWC does not authorize such use.

Under international law, a State may enforce a law only if it has jurisdiction to prescribe the law. ${ }^{72}$ The rules on prescriptive jurisdiction allow a State to prescribe domestic law for persons, conduct, and activities beyond its jurisdictional boundaries. International law on jurisdiction to enforce law contains, however, stricter limits: "It is universally recognized, as a corollary of state sovereignty, that officials of one state may not exercise their functions in the territory of another state without the latter's consent." ${ }^{\prime 3}$ Two fundamental principles support this position: (1) the principle of sovereignty and sovereign equality of States $;^{74}$ and (2) the principle prohibiting intervention in the domestic affairs of other States. ${ }^{75}$ Actions to enforce criminal law cannot be undertaken in the jurisdiction of another State without that State's consent.

These rules mean that Article II.9(d) permits a State Party to use toxic chemicals for law enforcement purposes only within areas subject to its jurisdiction. Under international law on enforcement jurisdiction, Article II.9(d) cannot be interpreted as allowing a State Party to use a toxic chemical to enforce its domestic law inside areas subject to the jurisdiction of another State. Such use would be legitimate only when (1) the CWC State Party with jurisdiction permits toxic chemicals to be used; (2) the permission relates to a law enforcement purpose; and (3) the use complies with the "types and quantities" requirement. ${ }^{76}$

71 State practice indicates frequent use of RCAs by governments within their sovereign territories. See Davison and Lewer 2004, op. cit. (note 11), pp. 34-35 (recording uses of RCAs around the world for crowd control).

72 American Law Institute, Restatement (Third) of the Foreign Relations Law of the United States, American Law Institute Publishers, St. Paul, 1986, 431(1). Under international law, a State has prescriptive jurisdiction with respect to (1) conduct, persons, or activities wholly or in substantial part within its territory or areas subject to its jurisdiction; (2) the activities, interests, status, or relations of its nationals outside as well as within its territory and areas subject to its jurisdiction; and (3) conduct outside its territory or areas subject to its jurisdiction (a) that has or is intended to have substantial effect within its territory, and (b) by persons not its nationals that is directed against the security of the State or against a limited class of other state interests. Ibid. $\$ 402$. Even with such a basis, the exercise of the jurisdiction must also be reasonable. Ibid, $\$ 403$. Ibid., p. 329.

74 Art. 2.1, UN Charter.

75 Ibid., Art. 2.7.

76 US State practice reflects this interpretation. The Commander's Handbook on the Law of Naval Operations lists as permissible the peacetime use of an RCA "[o]ff-base overseas for law enforcement purposes specifically authorized by the host government." Steven F. Day, "Legal considerations in noncombatant evacuation operations," Naval Law Review, Vol. 40, 1992, p. 45, p. 60. 
The international legal rules on jurisdiction to enforce law demonstrate that the ordinary meaning of "law enforcement" in Article II.9(d) incorporates the enforcement of domestic law within the State's own territory or areas subject to its jurisdiction. The ordinary meaning of "law enforcement" does not include the extrajurisdictional enforcement of domestic law because such enforcement depends entirely on the consent of another State.

\section{Use of toxic chemicals to enforce international law}

Whether Article II.9(d) allows the use of toxic chemicals to enforce international law is another question that has arisen. ${ }^{77}$ Does the ordinary meaning of "law enforcement" in light of the CWC's object and purpose include enforcement of international law?

To consider international law within the scope of "law enforcement" in Article II.9(d) would require an unconventional approach to the relationship between international law and enforcement. Whether international law is enforceable is a perennial debate that makes inclusion of that law within the ordinary meaning of "law enforcement" dubious. The decentralized and anarchic nature of international relations complicates its enforcement, hence the controversy: international law contains few centralized mechanisms under which States can compel other States to obey it. As "Oppenheim's International Law" noted, international law suffers deficiencies in the means available for enforcement of its rules. ${ }^{78}$ Thus, arguing that the ordinary meaning of "law enforcement" encompasses international law as well as domestic law lacks credibility, given the general relationship between enforcement and international law.

Enforcement of international law is also subject to principles regulating how States should handle disputes about violations of international law. Peaceful settlement of disputes is a generally applicable principle, ${ }^{79}$ according to which States must settle disputes without resort to force, violence and weaponry. States can take peaceful countermeasures (e.g. economic sanctions) to try to compel another State to comply with its international legal duties. Peaceful dispute settlement does not, however, contemplate use of toxic chemicals to compel obedience to international law. In fact, nothing in international law justifies one State using toxic chemicals to compel another State to comply with international law.

\section{Law enforcement and the right to use force in self-defence}

Some may argue that a CWC State Party can use toxic chemicals, pursuant to the law enforcement provision, in the exercise of its inherent right of self-defence against an armed attack or other form of illegal aggression by State or non-State parties. In other words, a State's use of the toxic chemicals would form part of the enforcement of international legal rules prohibiting the use of force. This

77 As Chayes and Meselson noted, the CWC "does not state explicitly what sources of law states may enforce in invoking Article II.9(d). It seems possible, therefore, that states might wish to invoke international law to justify their "law enforcement' activities." Chayes and Meselson, op. cit. (note 44), p. 15.

Arts. 2.3, 2.4 and 33.1, UN Charter. 
argument lacks any support in international law. Self-defence is an inherent right that States possess; it is not a "law enforcement" mechanism. ${ }^{80}$

Furthermore, the CWC's text, context, object and purpose point to the goal of eliminating the use of toxic chemicals in armed conflict. Allowing toxic chemicals to be used as part of the right of self-defence against aggression would make the use of chemical weapons permissible in armed conflict - the very thing the $C W C$ prohibits. The same reasoning applies to armed conflict conducted by the armed forces of a State outside its jurisdiction, whether such operations involve UN Security Council-authorized collective security responses, humanitarian intervention or anticipatory or pre-emptive self-defence.

\section{Extraterritorial law enforcement activities undertaken by military forces and permitted by international law}

Thus, Article II.9(d) does not allow CWC States Parties to use toxic chemicals to enforce international law. International law does, however, permit certain extraterritorial law enforcement activities by military forces in both traditional and non-traditional military operations. Such activities are within the scope of Article II.9(d).

International law recognizes a number of contexts in which military forces engage in law enforcement activities in connection with traditional military operations. These contexts generally relate to the preservation of public order and safety in areas subject to the control of military forces. First, IHL acknowledges the responsibility of the occupying power "to maintain the orderly government of the territory." ${ }^{\text {11 }}$ The International Committee of the Red Cross (ICRC) observed that this provision empowers the occupying power "in its capacity as the Power responsible for public law and order." 82 Fulfilment of this responsibility for public order and safety would include activities such as controlling civilian crowds in order to prevent disorder in the occupied territory.

Second, IHL also allows occupying forces to ensure the security of their members and property, of the occupying administration, and of the establishments and lines of communication used by them. ${ }^{83}$ This right gives occupying forces international legal permission to enact and implement penal legislation in order to protect their soldiers, administrators, buildings, lines of communication, equipment and other forms of property from problems created or threats posed by non-combatants in the occupied territory. ${ }^{84}$

80 Ibid., Art. 51.

81 Art. 64, Fourth Geneva Convention relative to the Protection of Civilian Persons in Time of War, 12 August 1949, UNTS, Vol. 75, p. 287 (hereinafter GC IV).

82 Commentary on Geneva Convention IV Relative to the Protection of Civilian Persons in Time of War, ICRC, Geneva, 1958, p. 337.

83 Art. 64, GC IV.

84 An example of the use of an RCA to protect the occupying power's property is described in a report on "non-lethal" weapons sponsored by the Council on Foreign Relations. In response to civilians infiltrating a military base in Baghdad occupied by US military forces and attempting to loot property, US military personnel used various "non-lethal" weapons, including a RCA, oleoresin capsicum (OC), to clear the civilians from the compound. Independent Task Force, Non-Lethal Weapons and Capabilities, Washington, D.C., Council on Foreign Relations, 2004, p. 51. See also Davison and Lewer 2005, op. cit. (note 11), pp. 22-24 (describing use of various NLWs in US military operations in Iraq and Afghanistan). 
Third, IHL recognizes that as well as the laws of the occupied territory, the occupying power may enforce laws it promulgates itself pursuant to its responsibilities under the international law of occupation. ${ }^{85}$ Such powers would include law enforcement techniques and weapons, such as RCAs, used to control civilian crowds and to protect public order and safety.

Fourth, IHL allows military forces to regulate the behaviour of prisoners of war (POWs).$^{86}$ Military forces can enforce laws, regulations and orders against $\mathrm{POWs}^{87}$ and may use weapons against POWs in extreme circumstances, such as attempts to escape ${ }^{88}$ after prior warnings appropriate to the circumstances are disregarded. According to the ICRC, the detaining power may use force against POWs engaged in rebellious or mutinous behaviour: "Before resorting to weapons of war, sentries can use others which do not cause fatal injury and may even be considered as warnings - tear gas, truncheons, etc." ${ }^{\text {99 }}$

These four contexts in which international law recognizes the legitimacy of extraterritorial law enforcement activities by military forces indicate that Article II.9(d) of the CWC includes these activities. This interpretation covers some of the circumstances in which the United States claims the ability to use RCAs in military situations, namely: (1) in areas under direct and distinct US military control, including the control of rioting POWs; and (2) in rear echelon areas outside the zone of immediate combat to secure convoys from civil disturbances. ${ }^{90}$

The above analysis also applies to non-traditional military activities, such as peacekeeping operations, recognized as legitimate under international law. Non-traditional military operations have legitimacy under international law if they are conducted pursuant to: (1) a request for peacekeeping forces from a sovereign State; and (2) the authorization of peacekeeping operations by the UN Security Council under Chapter VII of the UN Charter.

Military forces conducting peacekeeping operations will often find themselves responsible for the security of, and public order and safety within, civilian populations; will be involved in law enforcement operations (e.g. arresting suspected war criminals, rescuing hostages); and will face threats to the security of their personnel and equipment from non-combatants. ${ }^{91}$ Indeed, the challenges military forces face in handling civilian populations

86 Arts. 41, 82, Third Geneva Convention Relative to the Treatment of Prisoners of War, 12 August 1949, UNTS, Vol. 75, p. 135 (hereinafter GC III).

87 Ibid., Art. 82.

88 Ibid., Art. 42.

89 Commentary on Geneva Convention III Relative to the Treatment of Prisoners of War, ICRC, Geneva, 1960, p. 247.

90 Executive Order 11850, Federal Register, Vol. 40, 1975, p. 161, paras. (a), (d)).

91 After being unable to prevent violent mobs from attacking monasteries in Kosovo in March 2004, Germany announced its intention to equip its peacekeepers with RCAs. Davison and Lewer 2004, op. cit. (note 11), p. 34. In the Ivory Coast, French military forces used RCAs against rioting civilians in the wake of the French military intervention that followed an attack on French peacekeepers by the country's air force. Davison and Lewer 2005, op. cit. (note 11), p. 53. 
during peacekeeping operations have partly fuelled military interest in "nonlethal" weapons in the last decade. ${ }^{92}$

Thus, the CWC permits the use by military forces of RCAs for law enforcement purposes during non-traditional military operations sanctioned by international law. This interpretation is consistent with US claims that its military forces may lawfully use RCAs in (1) the conduct of peacetime military operations within an area of ongoing armed conflict when the United States is not a party to the conflict; (2) peacekeeping operations authorized by the receiving State, including peacekeeping operations pursuant to Chapter VI of the UN Charter; and (3) peacekeeping operations where force is authorized by the UN Security Council under Chapter VII of the UN Charter. ${ }^{93}$

This interpretation does not, however, support the US position that it may use RCAs against combatant forces in the above-listed nontraditional military operations. ${ }^{94}$ The types of law enforcement activities that international law allows military forces to undertake in traditional and nontraditional military operations relate to the interaction of military troops and non-combatants, in the form of either POWs or civilians, not the engagement of combatant forces.

The interpretation of Article II.9(d) as presented above has two implications that deserve mention. First, it means that in extreme law enforcement situations, military forces conducting extraterritorial law enforcement activities permitted by international law during traditional and non-traditional military operations might not be limited to the use of riot control agents. State practice suggests, however, that the CWC is more restrictive with regard to the use by military forces of toxic chemicals in such activities. Moreover, CWC States Parties, including the United States, have never claimed the ability to use, or actually used, toxic chemicals other than RCAs for the types of law enforcement activities permitted by international law in traditional and non-traditional military operations. ${ }^{95}, 96$ This more restrictive interpretation has two sources: (1) those activities are extraterritorial and do not benefit from the discretion accorded by international law to governments within their own territories; and (2) they are undertaken by military forces. The CWC's

92 Fidler, op. cit. (note 2), p. 58.

93 US Senate Executive Resolution No. 75 - Relative to the Chemical Weapons Convention, Congressional Record, Vol. 143, p. S3373-01, 17 April 1997, \$26A.

94 Ibid.

95 President Bush authorized US military forces to use RCAs in Iraq in 2003 under the circumstances described in Executive Order 11850. Neil Davison and Nicholas Lewer, Bradford Non-Lethal Weapons Research Project Report No. 4, 2003, p. 13. The UK military indicated in March 2003 that it would use RCAs in Iraq solely for riot control purposes. Davison and Lewer 2004, op. cit. (note 11), p. 34.

96 This situation has produced incentives for trying to fit new chemical compounds, such as malodorants, within the definition of an RCA, as the United States has done. Davison and Lewer 2003, op. cit. (note 95), p. 10. Such an approach will not, however, work for stronger incapacitating chemicals. As a National Research Council report observed, "[t] he use of calmatives had (..) been envisioned in connection with hostage situations and for use with 'unmanageable' prisoners, but not for riot situations in which incapacitated individuals might be trampled or crushed in the rioting." Committee for an Assessment of Non-Lethal Weapons Science and Technology, op. cit. (note 62), p. 27. 
object and purpose means that heightened scrutiny, and extra safeguards, are appropriate when extraterritorial military activities involving toxic chemicals are at issue.

The second implication of the above interpretation of Article II.9(d) is that it covers many, but not all, of the uses of riot control agents which the United States claims are legal under the CWC. It does not cover two situations in which the United States believes that the use of RCAs is legally permissible: (1) contexts in which civilians are used to mask or screen attacks and civilian casualties can be reduced or avoided; and (2) rescue missions in remote areas of downed aircrew and passengers, and of escaping POWs ${ }^{97}$ Neither of these situations resembles those in which military forces may engage in the kinds of law enforcement activities sanctioned by international law.

The use of riot control agents against enemy combatants attempting to capture downed aircrew and passengers or escaping POWs, or against enemy combatants who are employing civilians as human shields or to mask attacks, is more akin to a method of warfare than to a law enforcement purpose. Neither of these uses fits in with the kinds of law enforcement activities that are undertaken by military forces and sanctioned by international law. Interpreting Article II.9(d) in this manner is consistent with treaty interpretation principles because it distinguishes between law enforcement purposes permitted by Article II.9(d) and methods of warfare prohibited by Article I.5.

\section{Law enforcement and combating insurgencies}

Counter-insurgency operations in Iraq have raised the question whether military forces can use RCAs or incapacitating chemicals in counterinsurgency activities. In other words, can counter-insurgency operations mounted by military forces be considered a law enforcement purpose under Article II.9(d)? The insurgency context poses conceptual problems because it falls between traditional notions of armed conflict between States and law enforcement within a State. Environments involving insurgencies and largescale, organized civil violence have presented IHL with difficulties in the past, as evidenced by the controversies that surrounded the negotiation of Additional Protocol II on non-international armed conflict. It is therefore not surprising that the insurgency context creates problems for the interpretation of Article II.9(d).

International humanitarian law rules on non-international armed conflict apply to conflicts in the territory of a State between its armed forces and dissident armed forces or other organized armed groups which exercise such control over a part of that State's territory as to enable them to carry out sustained and concerted military operations. ${ }^{98}$ This threshold provides a demarcation point between armed conflict and law enforcement within a State. Thus,

97 Executive Order 11850, op. cit. (note 90), $\$($ b)-(c).

98 Art. 1, Protocol (II) Additional to the Geneva Conventions of 12 August 1949, and Relating to the Protection of Victims of Non-International Armed Conflicts, 10 June 1977, UNTS, Vol. 1125, p. 609. 
Additional Protocol II is a relevant source of applicable rules that should inform interpretation of Article II.9(d).

Military action taken against insurgents who exercise control over part of a State's territory and carry out sustained and concerted military operations constitutes armed conflict rather than law enforcement, and thus falls outside Article II.9(d). The CWC's prohibition of the use of chemical weapons "under any circumstance"99 encompasses civil conflict as well as international conflict. This reasoning also suggests that use of RCAs in counter-insurgency operations would be a method of warfare prohibited by Article I.5 of the CWC. The State practice of military forces in Iraq to date supports this interpretation, because such forces have not used RCAs or incapacitating chemicals in counter-insurgency operations.

\section{Moscow, law enforcement and the CWC}

The foregoing detailed analysis of the CWC's law enforcement provision is made in response to the shock waves that the use of fentanyl to end the Moscow hostage crisis sent through the debate on NLWs and international law. Most experts agreed that Russia's use of fentanyl fell within Article II.9(d), but uncertainty and worries about this provision's meaning and application with respect to contexts beyond the scenario in Moscow urgently needed to be resolved. The interpretation of Article II.9(d) presented above answers many questions raised about this provision and addresses fears that Moscow demonstrated it to be, as some had previously argued, "a grave weakness" making the CWC vulnerable to "advancing science and technology" 100 Admittedly, the law enforcement provision is complex, but analysis in the wake of Moscow indicates that it does not prostrate the CWC's object and purpose before benign or malevolent manipulation of advances in science and technology. Clarification of the provision is an important development after Moscow, but, as the next section argues, the impact of Moscow on the debate about NLWs and international law goes beyond determining the meaning of the law enforcement provision in the CWC.

\section{Beyond Moscow: Non-lethal weapons and international law today and tomorrow}

\section{Chemical and biological NLWs and international law: A sea change?}

Looking beyond the impact of the Moscow crisis on the interpretation of the CWC, a shift can be detected among important opinion leaders in the United States with regard to the prudence of pursuing chemical or biological NLW capabilities. This shift can be perceived in two reports by NLW task forces sponsored by the influential 
Council on Foreign Relations (CFR), one issued before the Moscow incident and one after. In 1999, a CFR task force discussing chemical and biological capabilities argued that "[o]n occasion, U.S. security might be improved by a modification to a treaty," ${ }^{101}$ which suggested a willingness on the part of opinion leaders in the United States to consider amending the CWC and/or the BWC.

Another CFR task force on non-lethal weapons reached, however, the opposite conclusion in 2004. This task force "considered the benefits that would accrue and the problems that would be posed by either a U.S. attempt to interpret the CWC or by a U.S. move to amend or to renounce the CWC in order to be able to use chemicals as nonlethal weapons against enemy combatants." 102 This analysis led the task force to conclude:

"The Task Force believes that to press for an amendment to the CWC or even to assert a right to use RCAs as a method of warfare risks impairing the legitimacy of all NLW. This would also free others to openly and legitimately conduct focused governmental $\mathrm{R} \& \mathrm{D}$ [research and development] that could more readily yield advanced lethal agents than improved nonlethal capabilities. (...) Accordingly, the Task Force judges that on balance the best course for the United States is to reaffirm its commitment to the CWC and the BWC and to be a leader in ensuring that other nations comply with the treaties." 103

The shift from the 1999 report to the conclusion reached by the 2004 report indicates a growth in awareness that loosening the strictures of the CWC or the BWC for "non-lethal" weapons purposes would not only harm US national security by providing incentives for others to pursue research easily exploited for lethal purposes but also - in the words of the 2004 CFR task force - damage the legitimacy of all NLWs. The 2004 CFR task force supported development of more NLW capabilities ${ }^{104}$ but concluded that keeping chemical or biological options open would undermine progress toward that goal. This task force wanted to avoid the deleterious policy and legal effects of the "fog of fentanyl" as part of the larger movement for more NLW development.

Other indications, too, support the conclusion that prospects and enthusiasm for more robust chemical capabilities are diminishing. Legal expert David Koplow has argued that amending the CWC to allow military use of "non-lethal" chemical weapons, whether RCAs or incapacitating chemicals, exists only in the realm of fantasy. ${ }^{105}$ A lawyer with the US Judge Advocate General admitted that the CWC prohibited military use of calmative chemical agents, calling into question the legality of any military interest in such incapacitating weapons. ${ }^{106}$

101 Independent Task Force 1999, op. cit. (note 35).

102 Independent Task Force 2004, op. cit. (note 84), p. 31.

103 Ibid., p. 32.

104 Ibid., p. 1.

105 Davison and Lewer 2005, op. cit. (note 11), p. 26 (reporting comments of NLW legal expert David Koplow at the Non-Lethal Defense Conference VI in March 2005).

$106 \mathrm{Ibid}$. (reporting a lawyer from the US Judge Advocate General as arguing that it was "more likely than not that the Chemical Weapons Convention prohibited these types [calmatives] of weapons systems."). 
The change in position of CFR task forces does not mean that interest in, or controversy about, chemical and biological NLWs for military purposes has evaporated. Some advocates continue to push for chemical and biological NLWs, which would require changing international law. ${ }^{107}$ Moreover, indications exist that military interest in incapacitating chemicals continues. ${ }^{108}$ A NATO report mentioned anti-matériel biological weapons as a technology of interest, ${ }^{109}$ despite the BWC's prohibition of such weapons ${ }^{110}$ and a prior NATO report that concluded that anti-matériel biological weapons were not permitted under the BWC. ${ }^{111}$ Arguments are being put forward that the CWC does not regulate malodorants, meaning that military forces could use them in armed conflict. ${ }^{112}$ Misgivings have been expressed that newer incapacitating chemicals will be called RCAs to provide cover for research and development under the guise of law enforcement purposes. ${ }^{113}$ In addition, concern is growing about so-called incapacitating "biochemical" weapons involving substances that might be classified as toxins under the BWC and/ or as toxic chemicals under the CWC. ${ }^{114}$ All these observations mean that international legal vigilance on NLW chemical, biological, and biochemical weapons remains important.

Nevertheless, the shift evident among CFR opinion leaders, combined with the sustained arguments and efforts of NLW sceptics, indicates that some "sea change" has occurred with regard to chemical and biological weapons in the

107 Davison and Lewer 2005, op. cit. (note 11), p. 21 (reporting that, at the Non-Lethal Defense Conference VI in March 2005, NLW advocate John Alexander held that "the issue of chemical and biological weapons should be revisited for non-lethal weapons purposes arguing that international law prohibiting their development is 'out-dated.'").

108 Dando, op. cit. (note 54), p. 17. One non-governmental organization has accused the United States of operating a secret chemical weapons programme in violation of the CWC. "US military operates secret chemical weapons program", Sunshine Project Aerogramme, No. 2002/05, Sunshine Project, 24 September 2002.

109 NATO Research and Technology Organization, Non-lethal weapons and future peace enforcement operations, TR-SAS-040, November 2004, p. 3-6.

110 See, e.g., Preliminary Legal Review of Proposed Chemical-Based Nonlethal Weapons, US Department of the Navy Office of the Judge Advocate General, 30 Nov. 1997, p. 21 ("The Biological Weapons Convention and, more clearly, the domestic [US] implementing legislation, prohibit the development, production, stockpiling of biological agents for use as weapons. Biological agents are broadly defined by the statute so as to include agents used for anti-material purposes.").

111 See Committees of the North Atlantic Assembly, Non-lethal weapons, Lord Lyell (United Kingdom) General Rapporteur, 18 April 1997, Doc. No. STC (97)3, at $\$ 39$ (stating that "the use of biological agents to render fuels inert or destroy materials used in material equipment would not be permissible under the BWC even if the intent was non-lethal.").

112 Massimo Annati, "Military use of chemical riot control agents: A case for legal assessment", paper presented to the 3rd European Symposium on Non-Lethal Weapons, 10-12 May 2005, Ettlingen, Germany, p. 7 (arguing that malodorants are not toxic chemicals under the CWC); Jared Silberman, "Non-lethal weaponry and non-proliferation," Notre Dame Journal of Law, Ethics and Public Policy, Vol. 19, 2005, pp. 347-348 (US Navy lawyer arguing that "[o]ne thing that you may see on the horizon is the use of malodorants - a way to deny access to an enemy.").

113 Davison and Lewer 2005, op. cit. (note 11), p. 26.

114 Neil Davison, "Weapons focus: Biochemical weapons," in Bradford Non-Lethal Weapons Research Project Report No. 5, May 2004, pp. 27-34; Wheelis, op. cit. (note 52), pp. 6-13; Malcolm Dando, "The malign use of neuroscience," Disarmament Forum, 2005, pp. 17-24; Kathryn Nixdorff, "Assault on the immune system," Disarmament Forum, 2005, pp. 25-35. 
debate about NLWs and international law after the Moscow crisis. Whether this sea change proves permanent or ephemeral bears watching in the next decade.

\section{The path less regulated: Other NLW technologies and international law}

As the Moscow crisis demonstrated and the latest CFR task force recognized, the chemical and biological paths to "non-lethal" weapons are fraught with intense controversy, much of which is connected to the "concentrated" manner in which international law regulates chemical and biological weapons. Other NLW technologies do not face the international legal scrutiny applied to chemical or biological agents. Nothing like the CWC or BWC exists for kinetic, acoustic, electrical, microwave and electromagnetic "non-lethal" weapon technologies; this creates a more conducive environment for research and development. The IHL and IHRL rules that apply are general in nature (e.g. no superfluous injury or unnecessary suffering from a weapon's use; no torture or other cruel, inhuman, or degrading treatment) rather than specific to a technology. This situation facilitates technologies moving from research and development to deployment. Although concerns about some of these technologies do exist, as illustrated by controversies surrounding Taser weapons, ${ }^{115}$ nothing like the "fog of fentanyl" currently complicates exploration of these NLW possibilities.

Interestingly, some "non-lethal" weapon advocacy seeks to prevent further density from developing in international legal regulation of these technologies. In November 2004, NATO's Research and Technology Organization (RTO) recommended that, "[i]n order to ensure that NATO forces retain the ability to accomplish missions, NATO nations must remain vigilant against the development of specific legal regimes which unnecessarily limit the ability to use NLW." 116 The RTO demonstrated no overt hostility to international law's role vis-à-vis NLWs, for it emphasized the duty of NATO countries to review the legality of new weapons and the need to determine whether IHL adequately addresses the use of "non-lethal" weapons. ${ }^{17}$ The desire to prevent further development of specific international legal regulation hints, however, at a concern that the debate on NLWs and international law has created momentum for, or at least serious interest in, international legal regulation of NLW technologies that threatens future military adoption and use of such technologies.

This recommendation underscores, however, a message of sceptics: there is no such thing as a "non-lethal" weapon. The RTO essentially wants the existing rules that apply to any new weapon to apply to NLWs. In other words, treat "non-lethal" weapons as simply weapons under existing rules. Sceptics have been arguing this position all along. The Moscow crisis also supports the argument that thinking of weapons as "lethal" or "non-lethal" is empirically and ethically suspect.

115 See Davison and Lewer 2005, op. cit. (note 11), pp. 34-41 (reviewing controversies surrounding the Taser weapon).

116 NATO Research and Technology Organization, op. cit. (note 109), p. iii.

117 Ibid., pp. 4-5. 
At the same time, the RTO's opposition to specific regulation of NLW technologies undercuts arguments put forward by advocates about why "nonlethal" weapons are ethically different. If a new technology requires, for humanitarian or other ethical reasons, additional rules on its development or use, then the ethically appropriate course of action would be new regulation of military development and use of that technology. ${ }^{118}$ Arguments that NLWs are ethically distinct rely on the ethics of existing IHL and IHRL as the moral baseline, which makes advocacy for no more specific regulation of new weapon technologies to enhance the military effectiveness of weapons ethically questionable.

In fairness to the RTO, it must be said that the recommendation opposed specific international legal regulations that "unnecessarily" limit military use of NLWs. But this qualifier begs the question as to what constitutes a necessary or unnecessary limit on the militarily effective use of a weapon. The fallout from the Moscow crisis, including the interpretation of the CWC's law enforcement provision, illustrates the value of specific international legal regulation of weapon technologies. The tension between the lessons from Moscow and the desire by some advocates to prevent further international legal regulation of NLW technologies is merely another manifestation of the old tension between military utility (defined by technology) and ethical principle (embodied in humanitarian law), a tension that IHL has been addressing since at least the late nineteenth century. The future of the debate about NLWs and international law will deeply involve both advocates and sceptics in grappling with this ancient tension against the backdrop of technological developments that promise to reshape the nature and art of war.

\section{Conclusion}

Davison and Lewer reported that, at a major "non-lethal" weapon conference in March 2005, advocates complained that they were losing the "public relations battle" over NLWs because of criticism from sceptics and the media. ${ }^{119}$ Frustration was evident that the critics and the media "just don't get it". ${ }^{120}$ Apparently, the critics and the media are not the only ones not "getting it." In 2004, the CFR task force on "non-lethal" weapons concluded that it "found little evidence that the value and transformational applications of nonlethal weapons are appreciated by the senior leadership of the Department of Defense. Despite success on the small scale, NLW have not entered the mainstream of defence thinking and procurement." 21

The disappointment of advocates with their lack of progress reflects the difficult environment shaped by many factors, including what happened in

118 The classic example of this dynamic is the development of the prohibition on the use of blinding laser weapons.

119 Davison and Lewer 2005, op. cit. (note 11), p. 21.

120 Ibid.

121 Independent Task Force 2004, op. cit. (note 84), p. 8. 
Moscow in October 2002. The meaning of Moscow was sobering to advocates and sceptics, requiring each side to revisit assumptions and arguments in order to gird for a difficult and complex future, particularly with regard to the role of international law. The "fog of fentanyl" presented both advocates and sceptics with a harsh reality that changed the context in which the future of "non-lethal" weapons would unfold.

The frustration of advocates at losing the public relations battle has deeper causes than a failure to market NLWs successfully. Many military leaders obviously remain sceptical of the utility of these weapons. Furthermore, as Moscow demonstrated, hard questions have to be asked of claims that weapons are "non-lethal" and are somehow ethically distinct because of their technology as opposed to their relationship with legal and ethical principles of behaviour. The arguments advocates used in the latter half of the 1990s to increase interest in "non-lethal" weapons no longer have the same traction in the current, more demanding environment. Some arguments, such as the ones advocating amendments to the CWC or BWC, have gone - even within the advocacy community - from being considered intellectually provocative to downright dangerous to the development of other technologies.

The meaning of Moscow also challenges sceptics. As analysed in detail in this article, the response to the terrorist attack at the Nord-Ost theatre forced more serious consideration of the law enforcement provision of the $\mathrm{CWC}$, the importance of which that response made all too clear. Furthermore, continuing interest in many non-chemical and non-biological NLW technologies means that the debate about "non-lethal" weapons and international law will continue for years, but with respect to technologies the development and use of which are not subject to arms control treaties. Post-Moscow, the next big test will come when technological breakthroughs in more advanced kinetic, electrical, acoustic, microwave or electromagnetic technologies occur and field deployment and use generates empirical data. ${ }^{122}$

What happened with respect to Moscow - recognition of space for "nonlethal" weapon use balanced by a need to apply, clarify and reinforce the parameters provided by international law - will characterize the NLW-international law relationship in the future as more advanced technologies mature. In short, the meaning of Moscow teaches that rapid technological change will continue to stress international law on the development and use of weaponry, but in ways more politically charged, legally complicated and ethically challenging than the application of international humanitarian law in the past to technologies specifically designed to kill and destroy.

122 See Steven Komarow, "Pentagon deploys array of non-lethal weapons", USA Today, 24 July 2005, at <http:// www.usatoday.com/news/world/iraq/2005-07-24-nonlethal-weapons_x.htm> (last visited 27 July 2005). At present, the pace at which such breakthroughs might happen is being slowed by a lack of funding. In the United States, commitments in Iraq and Afghanistan adversely affect prospects for Department of Defense support for development of NLW technologies. The research and development burden will fall, therefore, on the private sector. See Davison and Lewer 2005, op. cit. (note 11), p. 22. 